\title{
Article \\ Experimental Comparison of Innovative Composite Sorbents for Space Heating and Domestic Hot Water Storage
}

\author{
Vincenza Brancato $^{1}\left(\mathbb{D}\right.$, Larisa G. Gordeeva ${ }^{2}$, Angela Caprì ${ }^{1}(\mathbb{})$, Alexandra D. Grekova ${ }^{2}$ and Andrea Frazzica ${ }^{1, *(D)}$ \\ 1 Istituto di Tecnologie Avanzate per l'Energia “Nicola Giordano”, CNR ITAE, Via Santa Lucia sopra Contesse \\ 5, 98126 Messina, Italy; vincenza.brancato@itae.cnr.it (V.B.); angela.capri@itae.cnr.it (A.C.) \\ 2 Boreskov Institute of Catalysis, Novosibirsk, Ac. Lavrentiev av. 5, 630090 Novosibirsk, Russia; \\ gordeeva@catalysis.ru (L.G.G.); grekova@catalysis.ru (A.D.G.) \\ * Correspondence: andrea.frazzica@itae.cnr.it; Tel.: +39-090-624419
}

Citation: Brancato, V.; Gordeeva,

L.G.; Caprì, A.; Grekova, A.D.;

Frazzica, A. Experimental

Comparison of Innovative Composite

Sorbents for Space Heating and

Domestic Hot Water Storage. Crystals

2021, 11, 476. https://doi.org/

$10.3390 /$ cryst11050476

Academic Editors: Saman

Nimali Gunasekara, Sedigheh Bigdeli,

Alenka Ristić, Cemil Alkan,

Takahiro Nomura, Wangzhong Mu and Christoph Rathgeber

Received: 6 April 2021

Accepted: 21 April 2021

Published: 24 April 2021

Publisher's Note: MDPI stays neutral with regard to jurisdictional claims in published maps and institutional affiliations.

Copyright: (c) 2021 by the authors. Licensee MDPI, Basel, Switzerland. This article is an open access article distributed under the terms and conditions of the Creative Commons Attribution (CC BY) license (https:// creativecommons.org/licenses/by/ $4.0 /)$.

\begin{abstract}
In this study, the development and comparative characterization of different composite sorbents for thermal energy storage applications is reported. Two different applications were targeted, namely, low-temperature space heating $(\mathrm{SH})$ and domestic hot water (DHW) provision. From a literature analysis, the most promising hygroscopic salts were selected for these conditions, being $\mathrm{LiCl}$ for $\mathrm{SH}$ and $\mathrm{LiBr}$ for DHW. Furthermore, two mesoporous silica gel matrixes and a macroporous vermiculite were acquired to prepare the composites. A complete characterization was performed by investigating the porous structure of the composites before and after impregnation, through $\mathrm{N}_{2}$ physisorption, as well as checking the phase composition of the composites at different temperatures through X-ray powder diffraction (XRD) analysis. Furthermore, sorption equilibrium curves were measured in water vapor atmosphere to evaluate the adsorption capacity of the samples and a detailed calorimetric analysis was carried out to evaluate the reaction evolution under real operating conditions as well as the sorption heat of each sample. The results demonstrated a slower reaction kinetic in the vermiculite-based composites, due to the larger size of salt grains embedded in the pores, while promising volumetric storage densities of $0.7 \mathrm{GJ} / \mathrm{m}^{3}$ and $0.4 \mathrm{GJ} / \mathrm{m}^{3}$ in silica gel-based composites were achieved for SH and DHW applications, respectively.
\end{abstract}

Keywords: sorption; thermal energy storage; composites; space heating; domestic hot water

\section{Introduction}

The development of innovative and efficient energy storage technologies, able to support a wide penetration of renewables at different scales, is an urgent matter [1,2]. It mainly comprises electric (EES), mechanical (MES) and thermal energy storage (TES) technologies. In particular, the relevant role of TES in the whole energy system is confirmed by the most recent Eurostat analysis, reporting energy consumption at households dominated by space heating $(\mathrm{SH})(63.6 \%)$, followed by domestic hot water (DHW) (14.8\%) [3]. These values gain even more relevance considering that, again according to Eurostat, the residential sector accounts for $26.1 \%$ of the final energy consumption in Europe. This means that, overall, SH and DHW causes roughly $20 \%$ of the final energy consumption in EU, corresponding to about $3900 \mathrm{TWh} / \mathrm{y}$ [4]. In particular, a market analysis related to currently employed $\mathrm{SH}$ and DHW equipment installed in EU, demonstrated that the market is still dominated by gas boilers, both non-condensing, up to $67 \%$, and condensing ones, about $9 \%$ of total energy consumption. The other technologies comprise district heating networks (13\%) and electric radiators $(6 \%)$. The current diffusion of solar thermal collectors, representing the direct renewable sources, is limited to $2 \%$ [4]. This study confirms the reduced market penetration of renewables in the domestic heating sector, thus calling for innovative TES solutions acting as enabling technologies to unlock the potential of the renewable heating systems. 
The TES technologies are commonly classified depending on the physical process underpinning the TES operation, namely, sensible, latent, and thermochemical. The sensible TES [5,6] exploits the increasing temperature level of the storage media, to store thermal energy to be used subsequently. Accordingly, the overall storage capacity is directly dependent on the specific heat and temperature difference under which it is operated. This represents, especially for operation temperature below $100{ }^{\circ} \mathrm{C}$, the most common technology, since it exploits water as storage media. Nevertheless, it is characterized by low TES density and long-term storage limitation due to the unavoidable heat losses towards the surrounding environment, which reduce the amount of stored energy over time.

The latent TES [7] exploits the phase change (e.g., solid/liquid) occurring in the storage media when thermal energy is provided. The storage materials are often referred as phase change materials (PCMs). In this case, the most relevant thermophysical parameter useful to evaluate the TES density is the latent heat of phase transition. Of course, a certain portion of energy is also stored sensibly, due to the occurring temperature variation in the storage media. This technology is currently mainly commercialized for applications where the system needs to be operated in a narrow temperature range, exploiting the ability of latent TES to work almost isothermally at the phase change temperature. Examples are the preservation of vaccines and perishable food [8]. Even if characterized by higher energy storage density, thanks to the latent heat which is usually one order of magnitude higher than the specific heat, latent TESs are still suffering from heat dissipation, preventing their long-term reliability, as well as poor heat transfer efficiency due to the low thermal conductivity of the most common PCMs [9], which can be improved by using innovative nanofluids as heat transfer fluid [10].

The thermochemical TES [11,12] is based on the reversible reaction occurring between two components, to which a reaction heat is associated. Accordingly, during the charging phase, the thermal energy is supplied to the storage media to separate the two components through the endothermic reaction. While during the discharging phase, the reverse exothermic reaction of re-combination is performed, thus releasing the stored heat. This technology can be based either on chemical reactions, usually suitable for high temperature storage [13] or on physical interactions, characterized by lower heat and operating temperature [14]. This technology has gained a lot of attention thanks to the higher storage density achievable through the occurring reaction, as well as the possibility of keeping the energy stored almost indefinitely, as long as the two components are kept separated and no re-combination reaction is allowed (i.e., seasonal storage [15]). On the contrary, some of the main barriers towards its diffusion are represented by the highest system complexity, slow kinetic reaction, and issues in the long-term stability of the materials.

The thermochemical TES process commonly proposed for low-temperature storage (i.e., below $100{ }^{\circ} \mathrm{C}$ ) is usually referred as "sorption" [12] TES. Indeed, in this operating temperature range, it is possible to exploit physical or weak chemical reactions between a sorbate (often referred as working fluid) and a sorbent. Unlike the other technologies, the sorption TES needs to be operated at least between two different temperature levels, like reverse heat pumping cycles [16]. Indeed, during charging phase, it exploits the hightemperature source to be stored and an ambient sink where the reaction heat is dumped; while, during discharging phase, it exploits ambient heat as a source to promote the recombination process and it discharges the recovered heat at the end-user temperature level. This technology can be applied both as open and closed cycle. In the former one, the TES exchanges both mass and heat with the ambient conditions, accordingly it usually needs to exploit ambient humidity as sorbate $[17,18]$. In the latter one, only heat is exchanged with the ambient conditions, and the sorbate is continuously circulated inside the system, following the subsequent charging and discharging phases. The most common sorbate in closed systems is again water, even if other fluids were proposed that can be operated even at temperature below $0{ }^{\circ} \mathrm{C}$, such as ammonia [19], ethanol [20], and methanol [21]. While, regarding the sorbent, the main classification is between solid and liquid sorbents. In the solid sorbents, the reaction with the sorbate occurs on the available 
surface, mainly by means of weak physical interactions. The most common solid sorbents are zeolites [22], silica gel [23], zeotypes [24], and metal-organic frameworks [25]. In the liquid sorbents, the reaction occurs between a sorbate and a liquid solution. In this case, the most common proposed solutions are $\mathrm{LiBr} /$ water [26], $\mathrm{NaOH}$ /water [27] and, more recently, ionic liquids/water [28]. Both approaches show some limitations, such as the limited storage capacity achievable by pure physisorption processes, which is directly linked to the available specific pore volume of the solid sorbents [29], and the mass transfer limitation occurring in the reaction between a sorbate and a liquid solution [27]. A class of materials that can exploit the solid and liquid sorption storage features, also helping in overcoming the above listed limitations, is the composite sorbents class [14]. These materials are based on a solid porous matrix which is embedded with a salt. Accordingly, the interaction between the composites and sorbates combine several mechanisms: (i) the physisorption occurring on the matrix surface; (ii) the reaction with the embedded salt; and (iii) absorption by the salt solution forming inside the pores. This can substantially increase the achievable sorption capacity, which is reflected in higher storage density and, at the same time, it limits the mass transfer resistance in the reaction between salt and sorbate, since the grain size of the salt confined inside the pores is in the nano-scale.

In the literature, different matrixes and salts were proposed to synthesize the composites for TES applications. Usually, the main requests for the matrix is to have a large pore volume and an average pore size in the range $2-50 \mathrm{~nm}$ (i.e., mesoporous structure), thus allowing embedding of enough salt with reasonable crystal size. The selection of salt is strongly related to the boundary operating conditions.

The most common application for sorption TES is focused on SH provision, since, when low-temperature emission systems (i.e., radiant floors) are employed, the delivering temperature is low enough to achieve high storage density. For instance, in [30] an optimization of composite sorbents based on commercial mesoporous silica gels and $\mathrm{LiCl}$ was presented, aiming at maximizing the storage density for $\mathrm{SH}$ applications. The different samples were characterized from the morphological point of view as well as by detailed sorption equilibrium measurements. Starting from these characterizations, the theoretical storage density was estimated, showing promising storage densities up to $1200 \mathrm{~J} / \mathrm{g}_{\text {ads }}$. A different matrix was recently proposed for the same application, the multi-wall carbon nanotube (MWCNT) [21,31]. Composites based on $\mathrm{LiCl}$ and $\mathrm{LiBr}$ were synthesized in [21], showing an extremely high sorption capacity, both using water and methanol as sorbate. Specifically, the investigation performed for $\mathrm{SH}$ applications under seasonal operating conditions provided a theoretical storage capacity up to $1.70 \mathrm{~kJ} / \mathrm{gads}_{\text {ad }}$, for the composite using $\mathrm{LiCl}$ and water. Under the same conditions, the $\mathrm{LiBr}$ one looks more attractive when methanol is used as sorbate, achieving up to $0.46 \mathrm{~kJ} / \mathrm{g}_{\text {ads }}$. Another possible matrix proposed for the application is the vermiculite [32]. Differently from other matrixes, vermiculite is usually macro-porous, thus having higher pore volume but also wider pore size, causing a bigger crystal size of the embedded salt. This reflects on the higher sorption TES density achievable, which, as reported in [32], can be as high as $2.3 \mathrm{~kJ} / \mathrm{gads}$ for seasonal operating conditions. On the other hand, this can pose limitations on the sorption kinetic due to a larger salt grain size in the matrix. Concerning DHW provision, only a few examples were reported in the literature. For instance, a 4-kW prototype based on zeolite 13X and water with an open sorption TES was realized and tested in $[33,34]$. Of course, in this case the charging temperature is much higher than other cases, due to the high hydrophilicity of zeolite 13X. After a wide testing campaign, a storage density of about $0.29 \mathrm{GJ} / \mathrm{m}^{3}$ was obtained at prototype level. A composite based on $\mathrm{LiOH}$ and expanded graphite was presented in [35]. It was tested under conditions suitable for DHW provision. The employed charging temperature was $110^{\circ} \mathrm{C}$ and the achieved theoretical storage density was about $1 \mathrm{~kJ} / \mathrm{g}_{\text {ads }}$ for the composite that showed a stable behavior after repeated cycles. Nevertheless, the kinetic performance demonstrated the need to further investigate the applicability on a large scale. 
Starting from the literature analysis reported before, this paper presents, for the first time, a detailed comparison of different porous matrixes embedding two salts, optimized for SH and DHW storage applications. Water was selected as the sorbate, because it is environmentally benign and have a large evaporation heat. The comparative analysis starts from the structural and morphological characterization of the synthesized samples to end up with equilibrium and sorption storage capacity analysis under realistic operating conditions, to identify the most promising solutions for a large-scale sorption TES, able to supply both SH and DHW, thus increasing the share of renewables for heating purposes in domestic applications.

\section{Materials and Methods}

\subsection{Materials Selection}

As discussed above, composite sorbents are considered as one of the most attractive materials class for sorption TES (STES) applications. They employ a porous host matrix, usually characterized by a meso-porous distribution (i.e., pore diameter in the $2-50 \mathrm{~nm}$ range), embedding a hygroscopic salt increasing the overall sorption capacity of the material. Particularly, the nano-confinement of the salt inside the pores modify the behavior of the salt compared to its bulk configuration, thus allowing a real nano-tailoring of the sorption performance [36]. Furthermore, the embedding procedure allows overcoming issues typical of the pure salts, such as swelling after hydration/dehydration process and heat and mass transfer limitations. The obtained composite material is also characterized by a higher sorption capacity if compared to pure adsorbent materials commonly proposed for STES application, which means higher achievable storage capacities [32].

In the present paper, different commercial matrixes were selected to compare the achievable performance under STES application both for SH and DHW purposes. Accordingly, a market search was performed to identify possible candidates for the analysis. The main fixed constraints were the pore size, ideally in the mesoporous range $(2-50 \mathrm{~nm})$ or slightly larger and the pore volume, which should be as high as possible, to increase the amount of salt to be embedded. The threshold was fixed at $0.7 \mathrm{~cm}^{3} / \mathrm{g}$.

The three selected matrixes are represented in Figure 1 and the nominal features are summarized in Table 1.

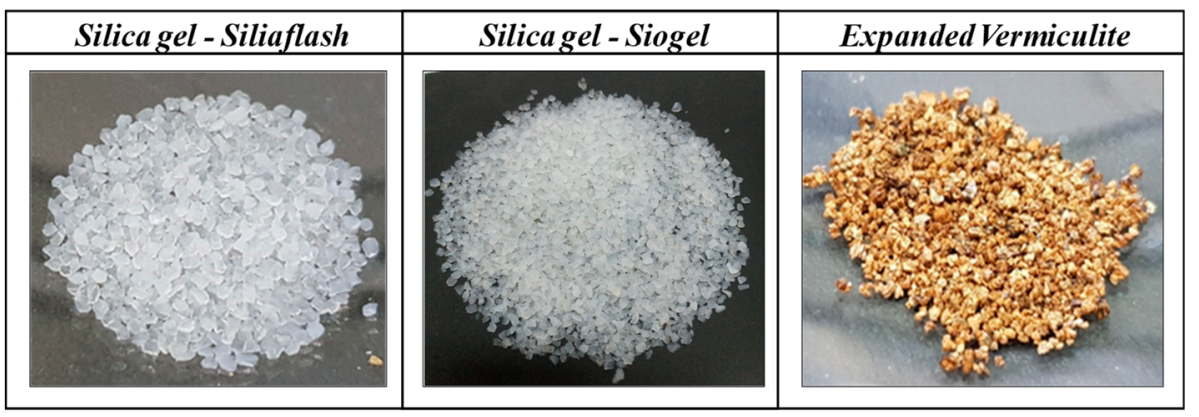

Figure 1. Pictures of the porous structure identified on the market.

Table 1. Nominal main characteristics of the porous structure identified on the market.

\begin{tabular}{|c|c|c|c|c|c|}
\hline Material & Particle Size (mm) & $\begin{array}{l}\text { Surface Area } \\
\left(\mathrm{m}^{2} / \mathrm{g}\right)\end{array}$ & $\begin{array}{l}\text { Nominal Pore } \\
\text { Volume }\left(\mathrm{cm}^{3} / \mathrm{g}\right)\end{array}$ & Pore Size (nm) & Price $(€ / 100 \mathrm{~kg})$ \\
\hline $\begin{array}{l}\text { Silica Gel—SiliaFlash }^{\circledR} \\
\text { (SiliCycle Inc., Quebec, } \\
\text { Canada) }\end{array}$ & $0.5-1.0$ & $\approx 250$ & 1.02 & $10-15$ & 2.196 \\
\hline $\begin{array}{c}\text { Silica Gel_Siogel }^{\circledR} \\
\text { (OKER-CHEMIE GMBH Im, }^{\text {Goslar, Germany) }}\end{array}$ & $1.5-3.5$ & $\approx 420$ & $0.6-0.85$ & $7-10$ & 610 \\
\hline Expanded Vermiculite (taly) & $2-4$ & - & 1.20 & $>20$ & 10 \\
\hline
\end{tabular}


As reported in Table 1, two silica gels (amorphous matrix) and an expanded vermiculite (crystalline matrix) were chosen. The two mesoporous silica gels present different features, in terms of particle size and porous structure, accordingly they were selected in order to compare the achievable performance of the composite sorbents. The expanded vermiculite has a macroporous structure, with much higher pore volume and pore size, thus allowing to highlight how the composite sorbent behavior is affected by those parameters. Furthermore, Table 1 also reports the cost of the identified matrixes, since it must be considered from the beginning, due to the expected large amount of material to be used for TES applications. It has to be pointed out that, in general, silica gels are more expensive than vermiculite, in particular the SiliaFlash one, developed for chromatographic applications.

The selection of suitable hygroscopic salts for composite sorbent manufacturing was based on the definition of working conditions and to the analysis of available adsorption equilibrium data in the literature. In order to easily compare different materials, adsorption equilibrium data collected from the literature were plotted as a universal adsorption curve "uptake $\mathrm{w}[\mathrm{g} / \mathrm{g}]$ vs. the Polaniy-Dubinin adsorption potential $\Delta \mathrm{F}[\mathrm{kJ} / \mathrm{mol}]=\mathrm{RT} \ln \left(\mathrm{p}_{\mathrm{s}} / \mathrm{p}\right)$ "

$$
\Delta F=R T \ln \frac{p_{s}}{p}
$$

where $\mathrm{T}[\mathrm{K}]$ and $\mathrm{p}[\mathrm{Pa}]$ are the temperature and pressure, respectively, at which the equilibrium is evaluated, and $\mathrm{p}_{\mathrm{s}}[\mathrm{Pa}]$, is the saturation pressure of the working fluid corresponding to the equilibrium temperature. In accordance with the Polanyi principle of temperature invariance, the adsorption potential may be used as a universal measure of the adsorbent affinity to sorbate vapor, since there is one-to-one correspondence between the uptake $\mathrm{w}$ and $\Delta \mathrm{F}, \mathrm{w}=\mathrm{f}(\Delta \mathrm{F})$ for many micro- and mesoporous adsorbents, including the composites [21,32,37]. This universal curve allows one to easily evaluate the amount $\Delta \mathrm{w}$ of sorbate, exchanged under operating conditions of a particular STES cycle as

$$
\Delta w=w\left(\Delta F_{\text {disch }}\right)-w\left(\Delta F_{\text {char }}\right)
$$

where $\Delta \mathrm{F}_{\text {disch }}$ and $\Delta \mathrm{F}_{\text {char }}$ are the $\Delta \mathrm{F}$-values, corresponding to the discharging and charging stages, respectively

$$
\begin{aligned}
& \Delta F_{\text {disch }}=R T_{\text {ads }} \ln \left[\frac{p_{s}\left(T_{\text {ads }}\right)}{p_{\text {eva }}}\right] \\
& \Delta F_{\text {char }}=R T_{\text {des }} \ln \left[\frac{p_{s}\left(T_{\text {des }}\right)}{p_{\text {con }}}\right]
\end{aligned}
$$

Table 2 summarizes the operating conditions defined for $\mathrm{SH}$ and DHW storage cycles. They are chosen under the assumption of seasonal heat storage application, accordingly, the charging phase occurs during the summer time, for this reason the condensation temperature, $\mathrm{T}_{\text {con }}$, is assumed at $35^{\circ} \mathrm{C}$ (i.e., ambient air temperature). The desorption temperature, $\mathrm{T}_{\mathrm{des}}$, representing the temperature level during charging phase, is assumed to be $90^{\circ} \mathrm{C}$ for $\mathrm{SH}$ applications, while it is considered slightly higher, i.e., $110{ }^{\circ} \mathrm{C}$ for DHW, to maximize the exploitability of the STES. During the discharging phase, occurring in winter, the evaporation temperature is considered at $5{ }^{\circ} \mathrm{C}$, assuming the possibility of exploiting either ambient heat or other low-temperature sources (e.g., geothermal, solar thermal under low irradiance). The adsorption temperature, corresponding to the useful temperature to be delivered to the user is assumed as $35^{\circ} \mathrm{C}$ for SH (i.e., low-temperature radiant floor distribution) and $55^{\circ} \mathrm{C}$ for DHW provision. $\Delta \mathrm{F}_{\text {disch }}$ and $\Delta \mathrm{F}_{\text {char }}$ values are calculated according to Equations (3) and (4). 
Table 2. Defined working operating conditions for both space heating and domestic hot water storage.

\begin{tabular}{ccccccc}
\hline Working Condition & $\mathbf{T}_{\text {des }}\left({ }^{\circ} \mathbf{C}\right)$ & $\mathbf{T}_{\text {con }}\left({ }^{\circ} \mathbf{C}\right)$ & $\mathbf{T}_{\text {ads }}\left({ }^{\circ} \mathbf{C}\right)$ & $\mathbf{T}_{\text {eva }}\left({ }^{\circ} \mathbf{C}\right)$ & $\begin{array}{c}\Delta \mathbf{F}_{\text {disch }} \\
(\mathbf{k J} / \mathbf{m o l})\end{array}$ & $\begin{array}{c}\Delta \mathbf{F}_{\text {char }} \\
(\mathbf{k J} / \mathbf{m o l})\end{array}$ \\
\hline $\begin{array}{c}\text { Space Heating (SH) } \\
\begin{array}{c}\text { Domestic Hot Water } \\
\text { (DHW) }\end{array}\end{array}$ & 90 & 30 & 35 & 5 & 4.8 & 8.4 \\
\hline
\end{tabular}

Figure 2 shows different equilibrium curves, reported in the literature for composite sorbents using various hygroscopic salts embedded in porous structures. Furthermore, the ranges of $\Delta \mathrm{F}$ corresponding to charging-discharging operation of STES for SH and DHW are represented. For the $\mathrm{SH}$ case, it is clear that, even if slightly varying with the different matrixes, the hygroscopic salt showing the most promising features is the $\mathrm{LiCl}$, that should be able to adsorb more than $0.4 \mathrm{~g} / \mathrm{g}$ of water under the defined operating conditions. Given the high discharging and charging temperature, the DHW storage operation is shifted towards higher $\Delta \mathrm{F}$ range. Under these operating conditions, $\mathrm{LiBr}$ that is characterized by a stronger affinity to water vapor and sorbs at a higher $\Delta \mathrm{F}$-values is selected as the best option, which could enable exchanging more than $0.1 \mathrm{~g} / \mathrm{g}$. Furthermore, the sorption properties of the composites can be managed by a proper selection of the salt content, thus enhancing their sorption capacity [14].

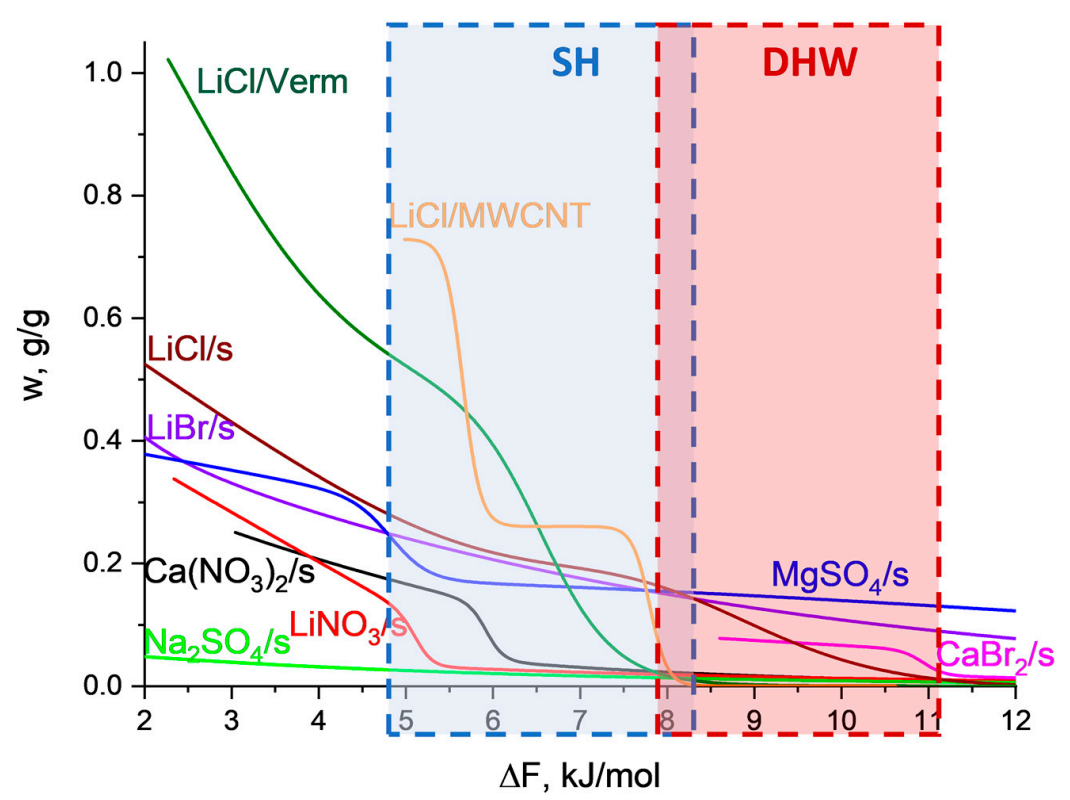

Figure 2. Comparative analysis of adsorption equilibrium of composite sorbents based on different hygroscopic salts as function of $\Delta \mathrm{F}$, to select the most promising salts for $\mathrm{SH}$ and DHW applications. The salt content equals $30(\mathrm{LiCl} / \mathrm{s}), 57(\mathrm{LiBr} / \mathrm{s}), 38\left(\mathrm{MgSO}_{4} / \mathrm{s}\right), 27\left(\mathrm{Na}_{2} \mathrm{SO}_{4} / \mathrm{s}\right), 34\left(\mathrm{LiNO}_{3} / \mathrm{s}\right)$, $46\left(\mathrm{Ca}\left(\mathrm{NO}_{3}\right)_{2} / \mathrm{s}\right), 40\left(\mathrm{CaBr}_{2} / \mathrm{s}\right), 59(\mathrm{LiCl} /$ Verm $)$, and $44(\mathrm{LiCl} / \mathrm{MWCNT}) \mathrm{wt} \%$, where $\mathrm{s}$ is silica gel, Verm-vermiculite, and MWCNT—MultyWall Carbon NanoTubes.

Accordingly, $\mathrm{LiCl}$ and $\mathrm{LiBr}$ were selected for the composite sorbents' preparation under SH and DHW conditions respectively. Both salts were provided by Sigma Aldrich with a purity grade of $>99 \%$.

\subsection{Composite Sorbents Manufacturing Process}

For the synthesis of the composite sorbents, the dry impregnation technique was applied $[38,39]$. The main phases of the process are schematically represented in Figure 3 : 
- The porous matrix and the inorganic salt are dehydrated for 8 to $12 \mathrm{~h}$, to eliminate the adsorbed water before the preparation phase.

- The salted solution is prepared by mixing the right amount of salt and distilled water, which depends on the salt to be embedded inside the porous structure. The solution is stirred until it becomes clear.

- The dry impregnation process is then performed by spreading the salt aqueous solution drop-by-drop over the matrix. The material is prepared inside a beaker, and mixed with a spatula for about $5 \mathrm{~min}$.

- As soon as the material is fully wet and the solution is completely used, the beaker is sealed and left for $2 \mathrm{~h}$ at room temperature (mixing every 20-30 $\mathrm{min}$ ).

- $\quad$ Finally, the sample is dried into an oven at $160{ }^{\circ} \mathrm{C}$ for $48 \mathrm{~h}$.

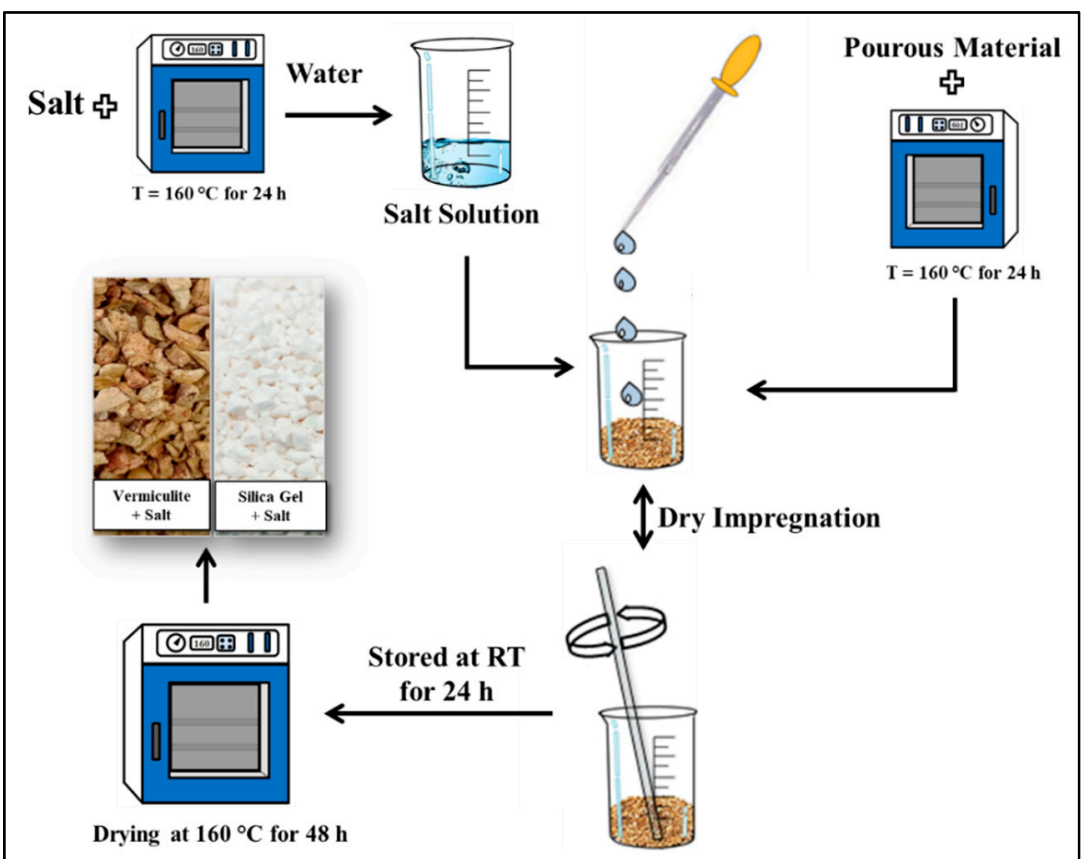

Figure 3. Schematic representation of the dry impregnation technique employed for the composite sorbent material preparation.

Starting from the identified materials introduced before, several compositions were realized according to the procedure described above and in Figure 3.

Table 3 summarizes the prepared compositions and the density of composite sorbent samples.

Table 3. Composition and density of the prepared composite sorbent materials.

\begin{tabular}{|c|c|c|}
\hline Sample & Salt Content (\%) & $\begin{array}{c}\text { Density of the Synthetized Composite } \\
\text { Sorbent Materials }\left(\mathrm{g} / \mathrm{cm}^{3}\right)\end{array}$ \\
\hline LiBr/Siogel & 51.10 & 0.86 \\
\hline $\mathrm{LiBr} /$ Siliaflash & 52.50 & 0.89 \\
\hline $\mathrm{LiBr} /$ Vermiculite & 63.30 & 0.49 \\
\hline $\mathrm{LiCl} /$ Siogel & 31.10 & 0.60 \\
\hline $\mathrm{LiCl} /$ Siliaflash & 32.40 & 0.63 \\
\hline $\mathrm{LiCl} /$ Vermiculite & 45.20 & 0.32 \\
\hline
\end{tabular}




\subsection{Characterization Methods}

\subsubsection{Porous Structures and Salts Characterization}

As the first step, the pristine materials (i.e., hygroscopic salts and porous matrices) used for the synthesis process were characterized. They were evaluated by means of $\mathrm{X}$-ray diffraction and nitrogen physisorption, for pristine salts and pure silica gels, respectively.

The X-ray powder diffraction (XRD) patterns were performed on the pure salts ( $\mathrm{LiBr}$ and $\mathrm{LiCl}$ ) in order to evaluate their purity and to have a reference pattern for the characterization of the impregnated materials. The experimental tests were carried out by means of a Bruker D8 Advance diffractometer (Bruker, Billerica, MA, USA), scan type: Coupled TwoTheta/Theta, measurement range: $10-80^{\circ}$, step size: $0.010^{\circ}$ in $0.1 \mathrm{~s}$, Voltage: 40 kV, Current: 40 mA, Anode: Cu (kalpha1: 1.54060 A, kalpha2: $1.54439 \AA$ ). Before each measurement the salts were dried in oven at $150^{\circ} \mathrm{C}$ overnight and the measurements were conducted at $90^{\circ} \mathrm{C}$.

Figure $4 \mathrm{a}, \mathrm{b}$ show the X-ray diffraction patterns obtained on the pure salts and the comparison against the reference peaks reported in the database [40,41]. Considering the position of the peaks, it is evident that the identified peaks are all in line with the expected ones, thus confirming the purity of the used materials. Nevertheless, a slightly deviation, that becomes consistent in the pure $\mathrm{LiCl}$, is found for the intensity of the peaks with respect to the diffractogram of the pure salts. The explanation of this, it could be ascribed to a different orientation of the crystallites.
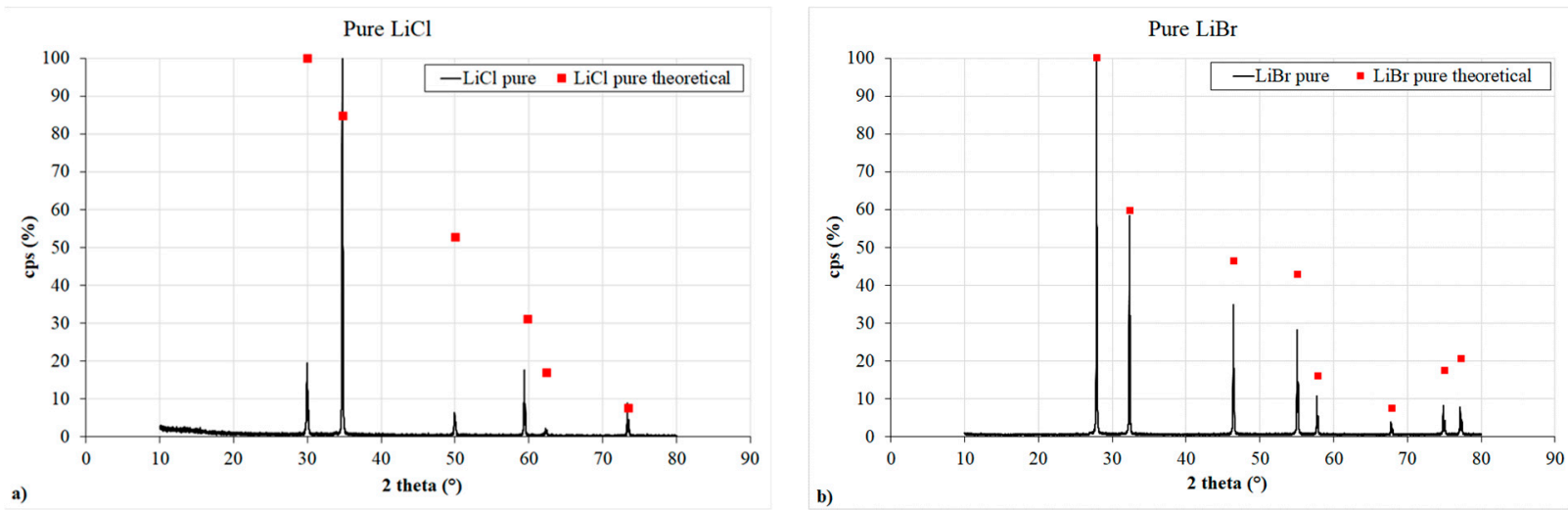

Figure 4. (a) XRD pattern of pure $\mathrm{LiCl}$; (b) XRD pattern of pure $\mathrm{LiBr}$.

The nitrogen physisorption was applied to the meso-porous structures, to evaluate the specific surface area, the pore volume and the pore size of the silica gels again in order to confirm the expected nominal values. In particular, the knowledge of the properties of the host matrices is of fundamental importance for the evaluation of the salt amount, which can be added to guarantee an optimal adsorption/desorption behavior.

The physisorption measurements were performed by means of Micromeritics ASAP 2020 (Micromeritics Instrument Corporation, Norcross, GA, USA). Prior to the measurements, the silica gels have been dried at $160{ }^{\circ} \mathrm{C}$ under continuous evacuation for $3 \mathrm{~h}$. Adsorption and desorption isotherms were performed in order to detect possible hysteresis effects.

The obtained isotherms reported in Figure $5 \mathrm{a}, \mathrm{b}$ can be categorized as Type IV(a), according to the IUPAC classification [42], demonstrating that both silica gels have mesoporous structures.

Accordingly, the BET (Brunauer-Emmett-Teller) theory was applied to determine the specific surface area of porous matrices. Cumulative volume of pores was evaluated from the nitrogen adsorption at relative pressure $p / p_{s}=0.99$. Finally, the pore width was calculated as $4 \mathrm{~V} / \mathrm{A}_{\mathrm{BET}}$. The results are summarized in Table 4 , being in line with the nominal data reported in Table 1. 


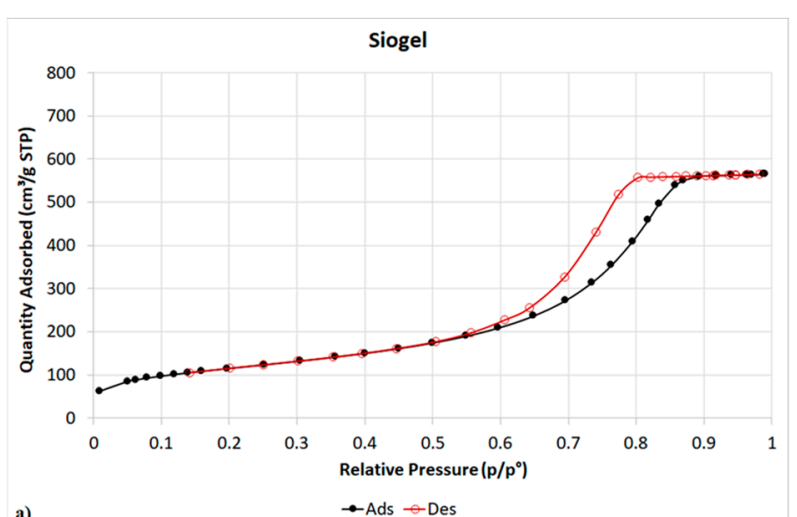

a)

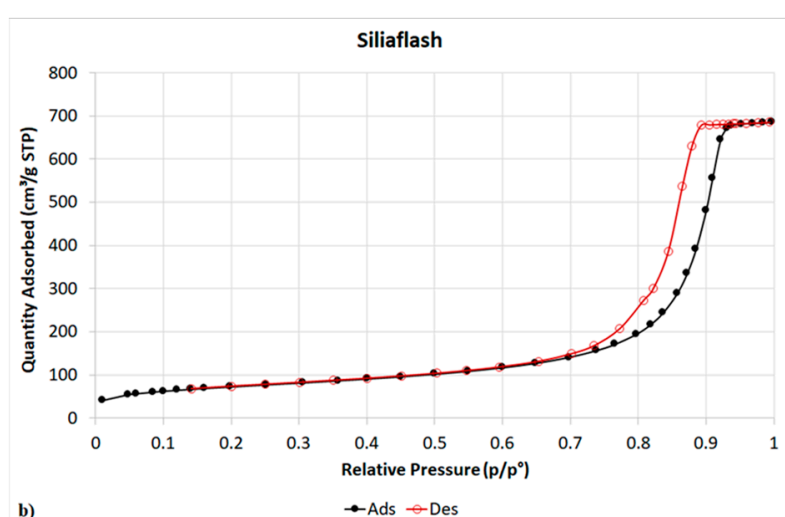

Figure 5. $\mathrm{N}_{2}$ ad-desoprtion isotherms of: (a) Siogel (b) Siliaflash.

Table 4. Nitrogen physisorption results for Siliaflash and Siogel.

\begin{tabular}{cccc}
\hline Sample & BET Surfece Area $\left(\mathbf{m}^{2} / \mathbf{g}\right)$ & Pore Volume $\left(\mathbf{c m}^{3} / \mathbf{g}\right)$ & Pore Size $(\mathbf{n m})$ \\
\hline Siliaflash & 262 & 1.06 & 16 \\
Siogel & 417 & 0.88 & 8 \\
\hline
\end{tabular}

$\mathrm{N}_{2}$ physisorption characterization was not applicable to the vermiculite porous structure, due to its macro-porosity which cannot be detected by this experimental procedure. The total pore volume was estimated as $1.6 \mathrm{~cm}^{3} / \mathrm{g}$ from the mass of liquid water soaked by the dry vermiculite during its immersion.

\subsubsection{Composite Sorbent Material Characterization}

In order to analyze the behavior of the synthesized composite sorbent materials, XRD characterization was performed varying the temperature over the samples. This was useful to investigate the crystalline phase transitions of the material due to the adsorbed water. The experimental tests were carried out by means of a Bruker D8 Advance diffractometer (Bruker, Billerica, MA, USA) in the same experimental conditions used for experiments of the pristine salts. The measurements were conducted under vacuum at $25^{\circ} \mathrm{C}$ and after 30 min that the samples were kept at $90^{\circ} \mathrm{C}$.

$\mathrm{N}_{2}$ physisorption measurements were performed only on the synthesized silica gelbased samples. The information that can be extracted from this analysis is of primary relevance to understand if the salt is well embedded inside the structure, occupying the available internal porosity. As reported by Brancato et al. [43], it is important that the composition of the composite sorbents is adequate to prevent two phenomena, that are: (1) oversaturation of the composite with water and the leakage of the formed aqueous salt solution out of the matrix's pores [14]; (2) the retardation of the sorption dynamics due to the so-called "blocking effect" [44]. Therefore, the knowledge of the pore volume before and after impregnation process allows one to characterize the nature of the salt deposition in the matrix as well as to analyze the space left for the water vapor flux inside the material. The experimental tests were carried out by means of ASAP 2020 produced by Micromeritics, Norcross, GA, USA. Prior to the measurements, the composite materials have been dried at $160{ }^{\circ} \mathrm{C}$ under continuous evacuation for $3 \mathrm{~h} . \mathrm{N}_{2}$ adsorption and desorption isotherms were performed in order to detect possible hysteresis effects. As before described, the isotherms were elaborated by means of the BET and BJH methods, to evaluate specific surface area and pore volume.

Water adsorption isotherms at $35^{\circ} \mathrm{C}$ of composite sorbent samples have been evaluated with a thermo-gravimetric technique based on the use of an automated vapor sorption analyzer (DVS Vacuum, Surface Measurement Systems Ltd., Alperton, Wembley, UK). The core of the instrument is a CAHN microbalance with the following features: sample mass $5-1000 \mathrm{mg}$, mass change: $\pm 150 \mathrm{mg}$, resolution (precision): $0.1 \mu \mathrm{g}$. The water uptake 
is calculated measuring the mass change of the sample during the adsorption process. The procedure used to carry out the tests consists of: loading 10-15 mg of the sorbent in the crucible inside the measuring chamber. Then, a first degas phase of the sample was performed at high temperatures $\left(150^{\circ} \mathrm{C}\right.$ in this case) and high vacuum $(10-4 \mathrm{kPa})$ for $8 \mathrm{~h}$ in order to evacuate and regenerate the sample. Once the sample was degassed, the dry mass was acquired and the measure of the equilibrium points, both in adsorption and in desorption phase, started.

A modified TG/DSC apparatus (i.e., Setaram LabsysEvo), whose main features are reported in [45], was employed in order to directly measure both sorption capacity and enthalpy of sorption. The core of the system is a Setaram Labsys-Evo analyzer (SETARAM, Caluire-et-Cuire, France), equipped with a standard TG/DSC rod, having a resolution of $10 \mu \mathrm{W}$ and characterized by $0.02 \mu \mathrm{g}$ of resolution and $0.02 \mathrm{mg}$ of accuracy. The testing procedure was defined as follows: $10 \mathrm{mg}$ of composite sample was placed into the measuring cell of the TG/DSC and degassed at $160{ }^{\circ} \mathrm{C}$ under continuous evacuation overnight. Then, the sample was cooled down to the initial adsorption temperature. The temperatures were selected to simulate the isobaric adsorption phase occurring during the discharging of the STES. The measuring cell was connected to the evaporator maintained at fixed temperature $\mathrm{T}_{\mathrm{ev}}$ for sorption. After the equilibration at the initial temperature, $\mathrm{T}_{\mathrm{in} . \mathrm{ads}}$, the temperature of the sample was dropped to the final discharging temperature $\mathrm{T}_{\mathrm{ads}}$ that results in water sorption from the sorbent material. The DSC signal was detected and the total amount of heat $Q$ was evaluated by integrating the DSC peak obtained.

\section{Results}

\subsection{X-ray Diffraction}

For each studied composite sorbent sample two different XRD patterns was recorded, the first one taken at RT (i.e., $25^{\circ} \mathrm{C}$ ), the second one after that the sample was kept for $30 \mathrm{~min}$ at $90^{\circ} \mathrm{C}$. The $2 \Theta$ range was always between $10^{\circ}$ and $80^{\circ}$.

As reference case, Figure $6 \mathrm{a}, \mathrm{b}$ reports the XRD patters obtained at $25^{\circ} \mathrm{C}$ of two samples based on Siogel and $\mathrm{LiCl}$ (Figure 6a) and $\mathrm{LiBr}$ (Figure 6b).

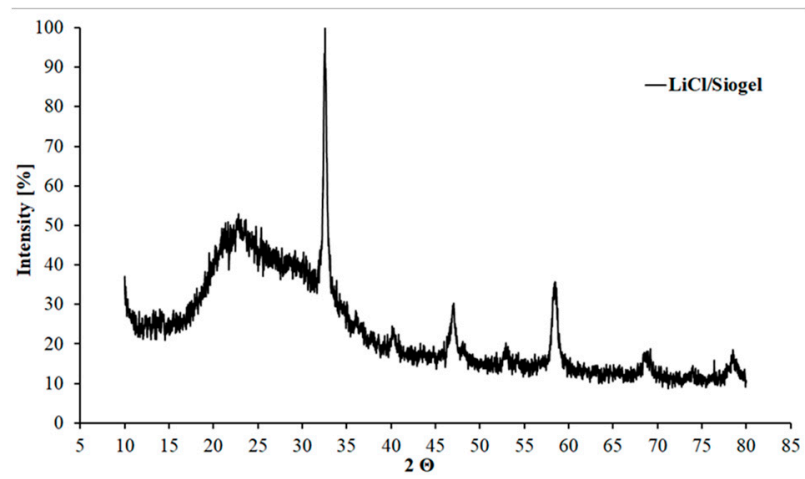

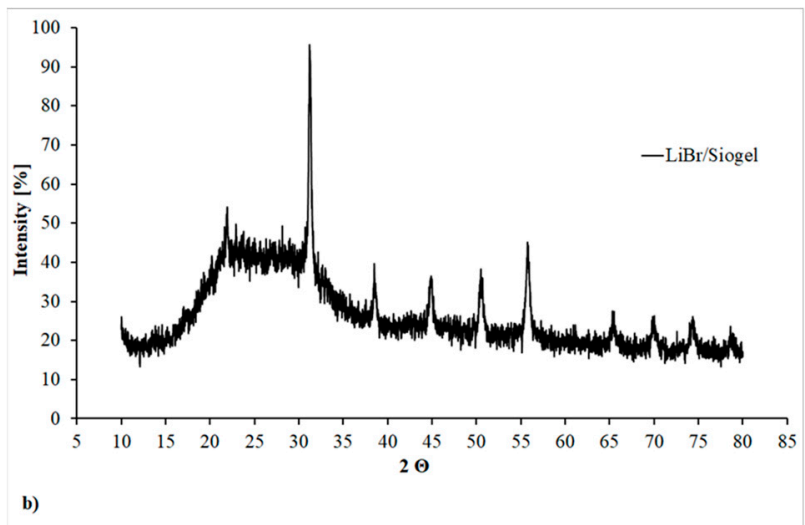

Figure 6. XRD patters of composite sorbents at $25^{\circ} \mathrm{C}$ : (a) $\mathrm{LiCl} / \mathrm{Siogel}$ sample; (b) LiBr/Siogel sample.

As expected, both XRD patterns reveal that composite samples present a relevant amorphous phase constituted by the silica gel matrix and also by the water molecules adsorbed in composite samples at $25^{\circ} \mathrm{C}$. Nevertheless, some peaks indicating the presence of crystalline structure are still present (Figure 4). These peaks can be assigned to the crystalline hydrates $\mathrm{LiCl} \cdot \mathrm{H}_{2} \mathrm{O}$ and $\mathrm{LiBr} \cdot \mathrm{H}_{2} \mathrm{O}$ formed through the reaction of the salts with ambient humidity [46].

Generally, an increasing crystallinity grade is common to all the studied composites passing from $25^{\circ} \mathrm{C}$ to $90^{\circ} \mathrm{C}$ and this confirms that the material is properly and quickly dehydrated without any kinetic hindrance. This is a feature related to the nano-confinement of small salt grains inside the porous structure. 
The XRD patterns of $\mathrm{LiCl}$ based samples that employ silica gel as matrix (Figure 7a,b), at $90{ }^{\circ} \mathrm{C}$, showed a highest and clearer diffraction peaks. This can be justified by the releasing of the adsorbed water present at low temperature, which implies presence of amorphous phase. This reported behavior is even more evident for the LiBr-based samples that employ silica gel as matrix (Figure $7 \mathrm{c}, \mathrm{d}$ ), probably because at $25^{\circ} \mathrm{C}$, the salt is mainly dissolved in the adsorbed water and forms the aqueous $\mathrm{LiBr}$ solution inside pores. After having heated up the material, the crystalline pattern of the $\mathrm{LiBr}$ salt is more evident.
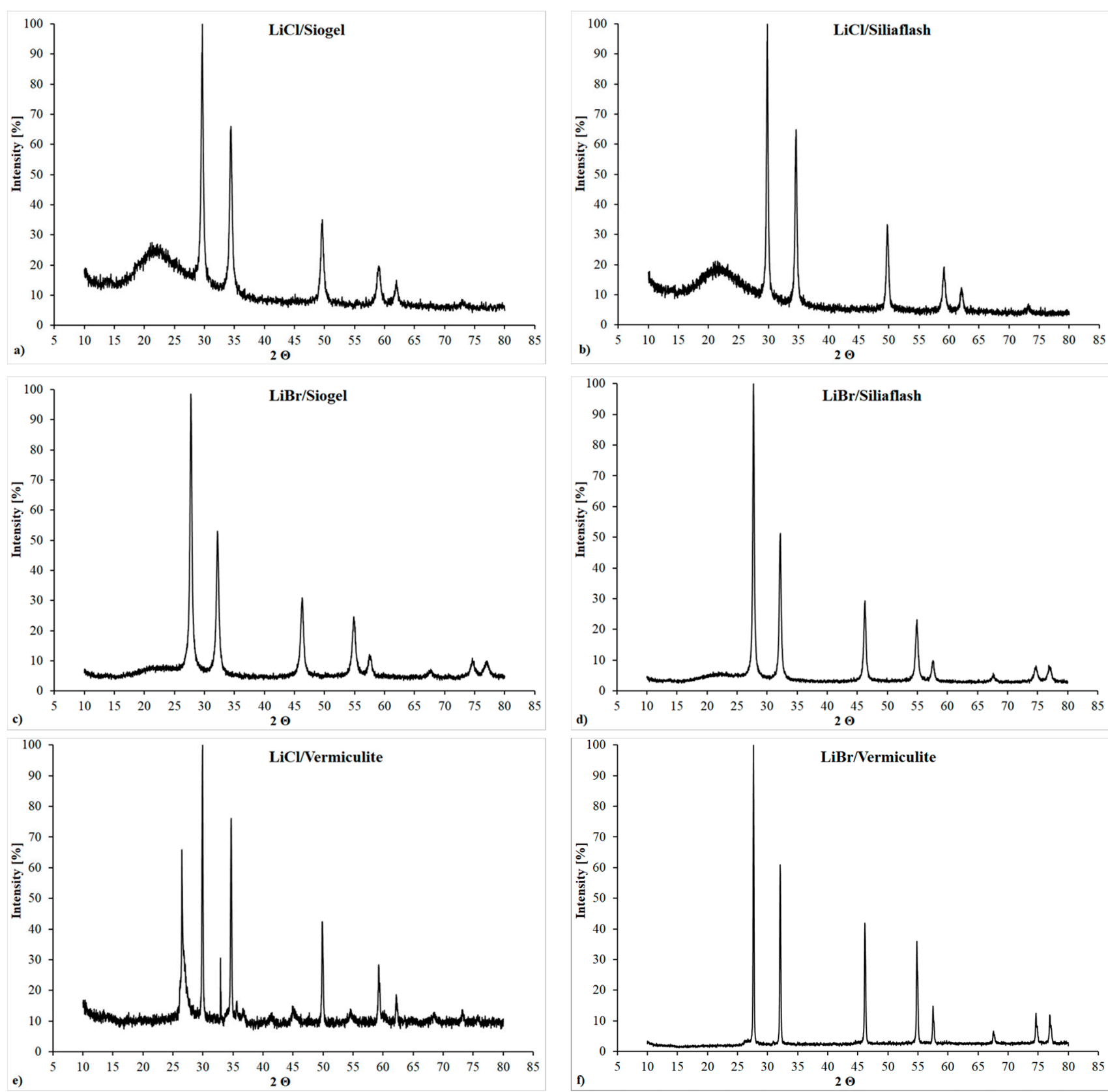

Figure 7. XRD patters of composite sorbents at $90{ }^{\circ} \mathrm{C}$ : (a) LiCl/Siogell; (b) LiCl/Siliaflash; (c) LiBr/Siogel; (d) LiBr/Siliaflash; (e) $\mathrm{LiCl} /$ Vermiculite; (f) $\mathrm{LiBr} /$ Vermiculite.

For the composite sorbents that employ $\mathrm{LiCl}$ and vermiculite as host matrix (Figure 7e,f), several peaks at $2 \Theta=26,33,42,45,54$ in the XRD patterns at $90^{\circ} \mathrm{C}$ may be attributed to the crystalline vermiculite structure. For $\mathrm{LiBr} /$ vermiculite the intensity of these peaks is negligible compared to the pure $\mathrm{LiBr}$ due to its larger content. 
The size of coherently scattering domains is around to $14 \mathrm{~nm}$ and $20 \mathrm{~nm}$ for siogelbased composites and SiliaFlash based composites, respectively. These values agree with the pore size found for the pristine matrices, even though there might be a slight effect of the salt deposited outside the pores, causing the dimensions slightly larger than the pore size. For vermiculite-based composites the size of coherently scattering domains is about $33 \mathrm{~nm}$, which is somewhat larger that for silica-based composites due to larger pore size of the vermiculite.

\subsection{Nitrogen Physisorption}

Figure 8a-d report the $\mathrm{N}_{2}$ ad/desorption isotherms obtained for silica gel based composite sorbents. The results demonstrate that all the $\mathrm{N}_{2}$ isotherms at $77 \mathrm{~K}$ of the composite sorbents belong to Type IV(a), according to the IUPAC classification [37].
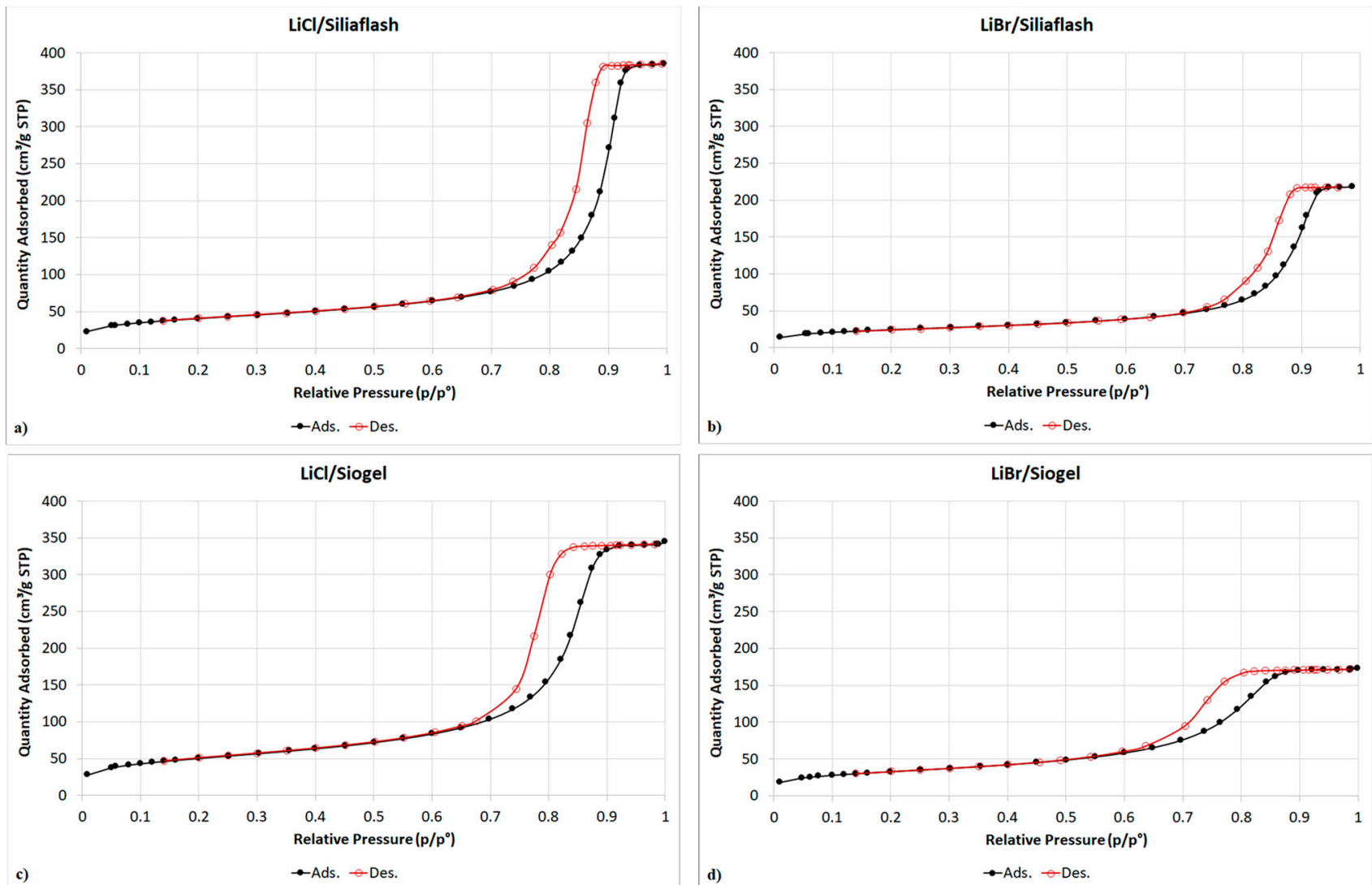

Figure 8. $\mathrm{N}_{2}$ physisorption isotherms evaluated for the silica gel based composite sorbent materials: (a) LiCl/Siliaflash samples; (b) LiBr/Siliaflash sample; (c) LiCl/Siogel sample; (d) LiBr/Siogel sample.

Table 5 summarizes the results in terms of BET surface area and pore volume. The physisorption tests allow to estimate the real amount of salt deposited as well as to analyze the space left for the water vapor flux inside the material, knowing the pore volume before and after impregnation process.

Table 5 also shows the features of the porous structure of the prepared composites based on silica gel matrix, as well as the theoretical pore volume $V_{p . t h}\left(\mathrm{~cm}^{3} / \mathrm{g}\right)$, calculated considering the salt is completely deposited inside silica pores and does not block them, according to the following equation

$$
V_{p, t h}=V_{p, m}\left(1-\frac{C_{s}}{100}\right)-\frac{C_{s}}{100 \rho_{s}}
$$


where $\mathrm{V}_{p . m}\left(\mathrm{~cm}^{3} / \mathrm{g}\right)$ is the matrix pore volume, $\mathrm{C}_{\mathrm{s}}(\mathrm{wt} \%)$ is the salt content, and $\rho_{s}\left(\mathrm{~g} / \mathrm{cm}^{3}\right)$ is the salt density.

Table 5. Achieved results in terms of BET surface area and pore volume for silica gel based composite sorbents.

\begin{tabular}{|c|c|c|c|c|}
\hline Sample & $\begin{array}{l}\text { BET Surface } \\
\text { Area }\left(\mathrm{m}^{2} / \mathrm{g}\right)\end{array}$ & $\begin{array}{c}\text { Total Pore } \\
\text { Volume }\left(\mathrm{cm}^{3} / \mathrm{g}\right)\end{array}$ & $\begin{array}{l}\text { Theoretical } \\
\text { Pore Volume } \\
\left(\mathrm{cm}^{3} / \mathrm{g}\right)\end{array}$ & $\begin{array}{l}\text { Pore Volume } \\
\text { Reduction (\%) }\end{array}$ \\
\hline Siliaflash & 262 & 1.06 & - & - \\
\hline $\mathrm{LiCl} /$ Siliaflash & 145 & 0.59 & 0.56 & 43.8 \\
\hline LiBr/Siliaflash & 88 & 0.33 & 0.35 & 68.2 \\
\hline Siogel & 417 & 0.88 & - & - \\
\hline $\mathrm{LiCl} /$ Siogel & 182 & 0.53 & 0.46 & 39.9 \\
\hline $\mathrm{LiBr} /$ Siogel & 118 & 0.26 & 0.28 & 69.6 \\
\hline
\end{tabular}

As expected, these parameters follow the same trend of the pure porous matrixes. The pore volume reduction seems to be in line with amount of embedded salt, thus confirming that the salt can be considered deposited inside the pores.

The samples based on $\mathrm{LiCl}$ present a theoretical pore volume slightly smaller than the experimental one, which implies that salt is partially located out of pores. While, composite sorbents based on $\mathrm{LiBr}$ present a theoretical pore volume larger than experimental one. This could indicate that the pores are partially blocked by either LiBr particles deposited on the external surface of the composite's grains, or by LiBr crystals placed inside pores necks. In any case, it is evident that most of the salt is actually embedded inside the pores, since a maximum deviation of about $10 \%$ was encountered.

\subsection{Equilibrium Curves of Water Adsorption}

The equilibrium curves of water vapor adsorption, reported in Figure 9a-f, were collected by measuring the ad/sorption isotherms at $35^{\circ} \mathrm{C}$. The choice of this temperature was established considering the discharge temperature of a storage system under $\mathrm{SH}$ operating conditions and were used for an initial screening of adsorbent materials performance.

At low relative humidity $<3$ and $5 \%$ for $\mathrm{LiCl} /$ silica and $\mathrm{LiCl} /$ vermiculite-based composites a small mass of water is adsorbed on the matrix surface (Figure $9 \mathrm{~d}-\mathrm{f}$ ). At increasing humidity, the $\mathrm{LiCl}$ reacts with water resulting in formation of the hydrate $\mathrm{LiCl} \cdot \mathrm{H}_{2} \mathrm{O}$ that reveals as the step on adsorption isotherms. At increasing humidity, the hydrate deliquesces and the forming solution absorbs water vapor that corresponds to the gradual increase in the uptake.

The isotherms of the composites employing $\mathrm{LiBr}$ are shifted toward a lower humidity that indicates its stronger affinity to water. Again, the step attributed to the formation of $\mathrm{LiBr} \cdot \mathrm{H}_{2} \mathrm{O}$ is observed, which is followed by the smooth uptake growth corresponding to the water absorption by $\mathrm{LiBr}$ aqueous solution inside pores. From the obtained isotherms it is easy to observe that the behavior of composite sorbents depends on the matrix and on the embedded salt. Generally, the sorbents made by silica gel matrices show smoother $\mathrm{de} /$ adsorption de/increment of the uptake (Figure $9 \mathrm{a}, \mathrm{b}, \mathrm{d}, \mathrm{e}$ ), while the sorbents based on vermiculite present distinct steps of de/adsorption (Figure $9 c-f$ ). This difference is probably due to a larger size of the salt crystals inside pores.

The maximum uptake is higher for composite sorbents based on the vermiculite and this result is in line with the salt content. 

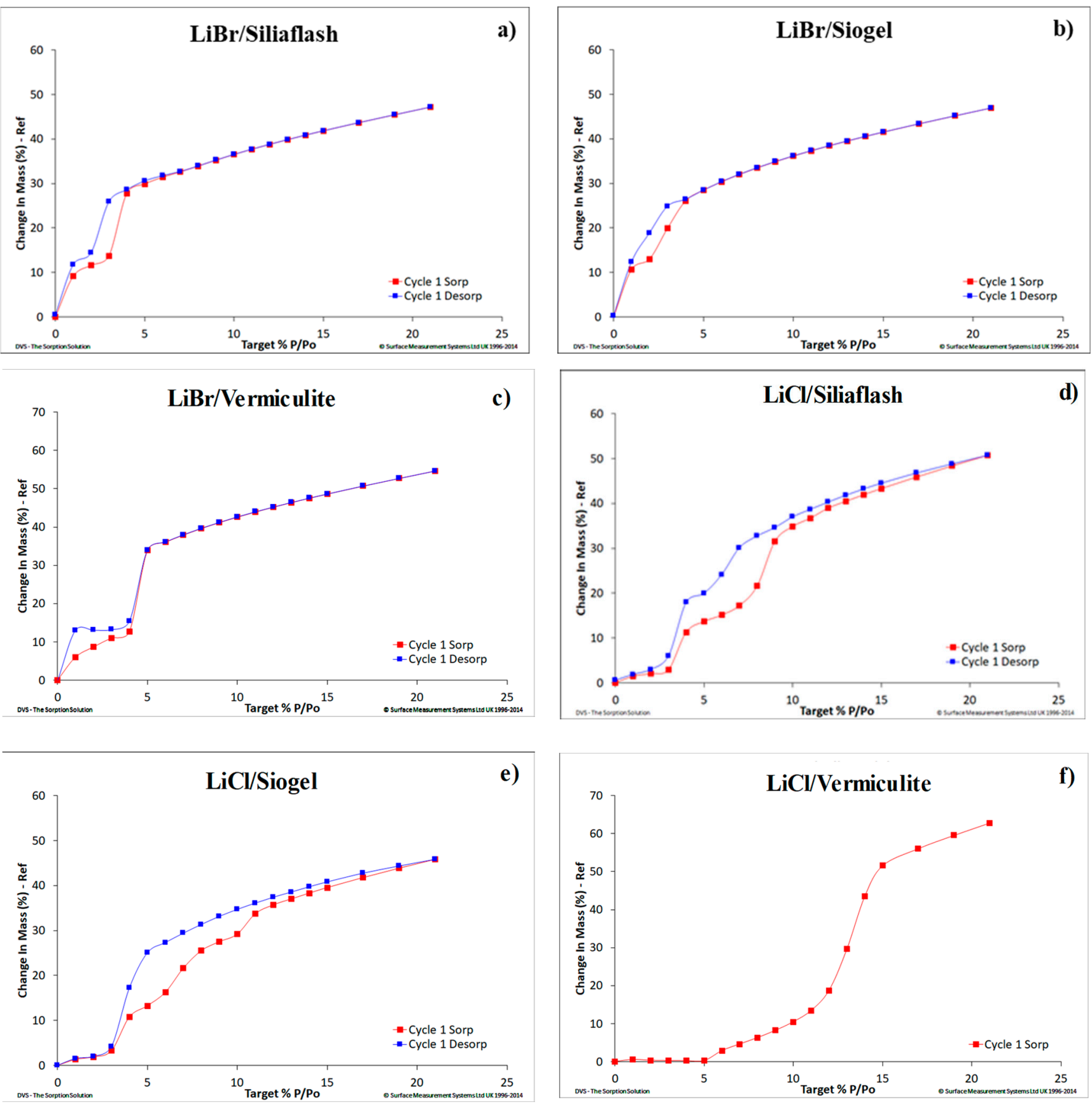

Figure 9. Equilibrium isotherms evaluated at $35{ }^{\circ} \mathrm{C}$, in a relative pressure range from 0 up to $23 \%$ : (a) $\mathrm{LiBr} / \mathrm{Siliaflash}$ sample; (b) $\mathrm{LiBr} /$ Siogel sample; (c) $\mathrm{LiBr} /$ Vermiculite sample; (d) LiCl/Siliaflash sample; (e) $\mathrm{LiCl} /$ Siogel sample; (f) $\mathrm{LiCl} / \mathrm{Vermiculite}$ sample.

\subsection{Coupled TG/DSC}

In order to evaluate the achievable energy storage density, the sorption heat was measured for the prepared composites under pure water vapor atmosphere, to simulate the typical operation of STES working with a closed cycle. Specifically, according to the boundaries reported in Table 2, an evaporation pressure $p_{\mathrm{ev}}$ of $8.7 \mathrm{mbar}$, corresponding to $5{ }^{\circ} \mathrm{C}$ of evaporation temperature was considered for all the tests. The initial temperature, $\mathrm{T}_{\mathrm{in} \_a d s}$, of the isobaric adsorption stage was selected in such a way, that the value $\Delta \mathrm{F}_{\text {in_ads }}=$ $\mathrm{RT}_{\text {in_ads }} \ln \left(\mathrm{p}_{\mathrm{s}}\left(\mathrm{T}_{\mathrm{in} \_ \text {ads }}\right) / \mathrm{p}_{\mathrm{ev}}\right)$ equals the value of $\Delta \mathrm{F}_{\text {char }}$ of the appropriate STES cycle (Table 2). In accordance with the Polanyi principle of temperature invariance, the uptake $\mathrm{w}\left(\Delta \mathrm{F}_{\text {in_ads }}\right)$ $=\mathrm{w}\left(\Delta \mathrm{F}_{\text {char }}\right)$. Thus, the TG/DSC tests imitate the selected STES cycles. Accordingly, 
starting temperature $\mathrm{T}_{\text {in_ads }}=66$ and $80^{\circ} \mathrm{C}$, were considered for $\mathrm{SH}$ and DHW storage applications, respectively. For comparison purpose, the tests were performed also at two higher temperatures $\mathrm{T}_{\text {in_ads }}=80$ and $9{ }^{\circ} \mathrm{C}$ for $\mathrm{SH}$ and DHW storage applications, respectively. The adsorption temperature, $\mathrm{T}_{\text {ads }}$, was selected according to Table 2 , namely, $35^{\circ} \mathrm{C}$ for $\mathrm{SH}$ and $55^{\circ} \mathrm{C}$ for DHW.

Figure 10 reports, for comparison purposes, some reference dynamic evolutions obtained during the TG/DSC characterization. Specifically, the tests over Siogel-based and vermiculite-based composites employing $\mathrm{LiCl}$ and $\mathrm{LiBr}$, under the same operating conditions are described. Each evolution reports the measured heat flow, along with the peak integration needed to evaluate the sorption heat, the mass variation and the first derivative of the mass variation, $\mathrm{dm} / \mathrm{dt}$. Since all the measurements refer to an adsorption stage, a mass increasing is always obtained. As can be highlighted by Figure 10a,b, the obtained evolution for composites based on $\mathrm{LiCl}$, employing Siogel and vermiculite are quite different. Indeed, while the sample based on silica gel has a single non-symmetrical adsorption peak, which also corresponds to a single peak of the $\mathrm{dm} / \mathrm{dt}$ signal, in the vermiculite sample the heat flow signal is characterized by two consecutive peaks that are also associated with two peaks observed in the $\mathrm{dm} / \mathrm{dt}$ signal. This difference can be justified with the larger size of the salt grains embedded in the vermiculite pores, which slow down the hydration reaction with the water vapor, especially at such a low absolute pressure. This effect is even more pronounced for the LiBr-based composites. Also in this case, Siogel and vermiculite are compared. A narrow reaction peak is obtained for the silica gel-based sample, while a much broader peak is obtained for the vermiculite-based one. Indeed, in the latter case, after an initial heat flux peak, corresponding to a dm/dt peak, a plateau is observed, until the reaction process is over, and the heat flux as well as the $\mathrm{dm} / \mathrm{dt}$ suddenly drop. This behavior can be ascribed to the large amount of LiBr embedded in the vermiculite pores, as represented in Table 5, and a larger crystal size, which is reflected in a behavior of the salt closer to the bulk rather than to the nano-confined one. Of course, from the practical operation point of view, this behavior implies that the vermiculite-based samples are characterized by a slower reaction kinetics, which can limit the discharging power during operation.

The synthesized samples were tested under the above conditions. Each test consisted of four consecutive adsorption drops inside the TG/DSC apparatus, in order to guarantee the replicability of the measurement. All the samples showed a good reproducibility of the results, with a deviation of $5 \%$ maximum. The heat flux peaks were integrated to obtain the sorption heat and the corresponding water uptake variation was calculated. Figure 11 summarizes the achieve results. For each sample and each temperature drop tested, the orange bar represents the uptake variation in $(\mathrm{g} / \mathrm{g})$, while the green bar represents the sorption heat in $\left(\mathrm{GJ} / \mathrm{m}^{3}\right)$, evaluated considering the sample densities reported in Table 3 .

As expected, both water uptake variation and sorption heat obtained for DHW operation are much smaller than the ones measured for SH applications. Interestingly, the obtained results are almost unaffected by the initial adsorption temperatures applied. This means that, at the investigated water vapor pressure, the composite sorbents already reached their minimum adsorption capacity at the lowest starting adsorption temperature, namely $66{ }^{\circ} \mathrm{C}$ for $\mathrm{SH}$ and $80{ }^{\circ} \mathrm{C}$ for DHW. Looking at the achieved results, composite sorbents based on vermiculite achieve the highest water uptake variation, namely about $0.18 \mathrm{~g} / \mathrm{g}$ for DHW and $0.52 \mathrm{~g} / \mathrm{g}$ for SH. The silica gel-based ones show, on average, a lower water exchange capacity ranging between $15 \%$ ( $\mathrm{LiBr}$ composites) and $25 \%(\mathrm{LiCl}$ composites) of the ones obtained with the vermiculite-based composites. This is due to the higher amount of salt confined in the pores of the vermiculite. Specifically, these values are in line with the salt content of the synthesized samples. Indeed, the $\mathrm{LiCl}$ embedded in the silica gel samples is roughly $30 \%$ lower than content embedded in the vermiculite, while for the $\mathrm{LiBr}$, this reduction is of about $20 \%$. This confirms that the salt represents the active part of the composite, which mainly sorbs water vapor. 


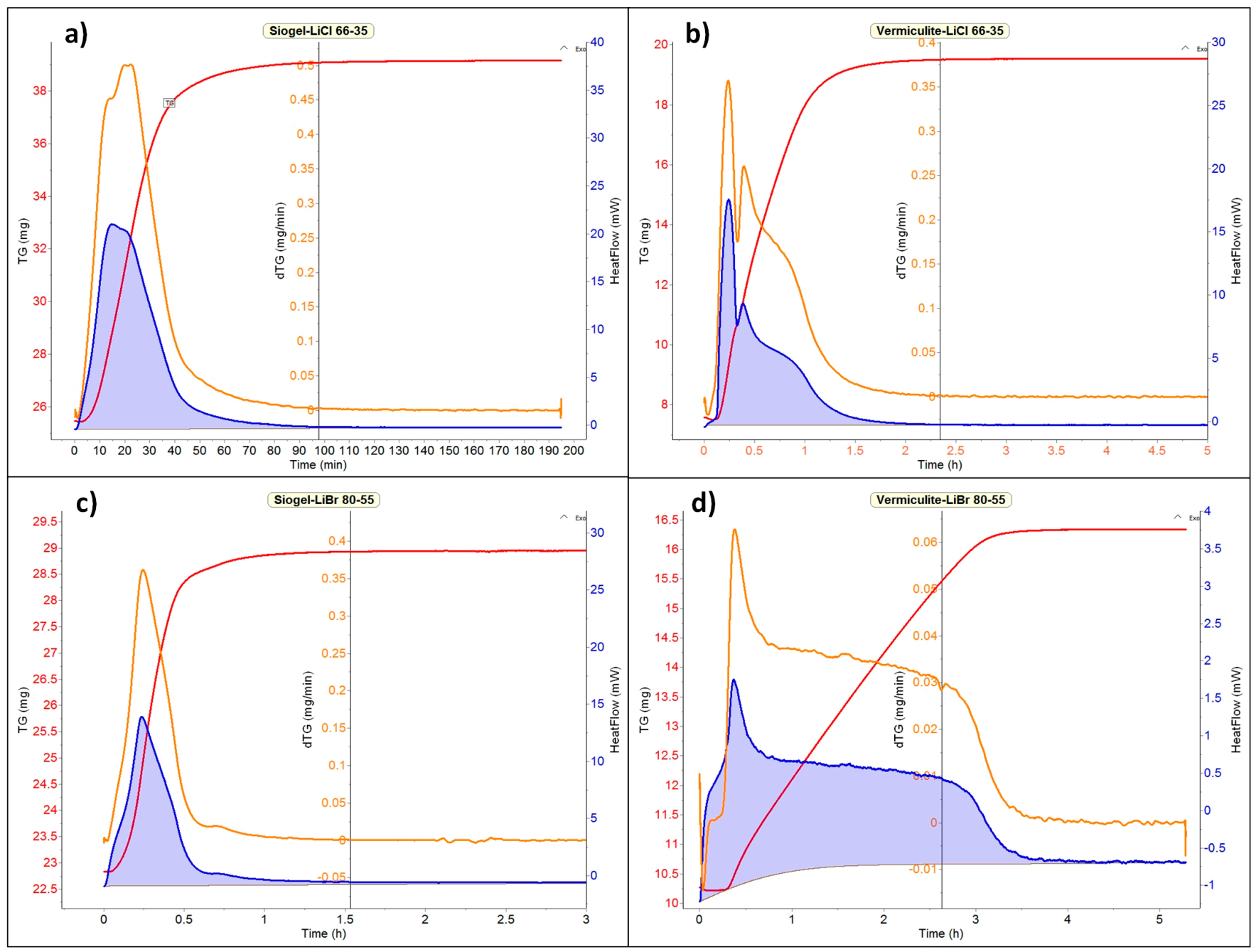

Figure 10. TG/DSC evolutions measured over LiCl-based samples, with siogel (a) and vermiculite (b) matrix respectively, under the temperature drop $66-35^{\circ} \mathrm{C}$ and LiBr-based samples, with siogel (c) and vermiculite (d) matrix respectively, under the temperature drop $80-55{ }^{\circ} \mathrm{C}$, at 8.7 mbar of water vapor pressure, corresponding to $5{ }^{\circ} \mathrm{C}$ of evaporation temperature.

On the other hand, looking at the corresponding volumetric sorption heat, the composites employing silica gel as matrix achieve the highest values, since the density is about $45 \%$ higher than the one of vermiculite samples. This represents a crucial parameter in order to obtain compact TES. Interestingly, the highest sorption heat for SH applications is obtained with the Siliaflash sample, which reaches up to $0.7 \mathrm{GJ} / \mathrm{m}^{3}$. This value is reduced to $0.6 \mathrm{GJ} / \mathrm{m}^{3}$ when Siogel is employed. This difference is due to the higher pore volume of the Siliaflash, which allows embedding a higher quantity of salt in the matrix. As highlighted, the $\mathrm{LiCl} /$ vermiculite achieves the lowest volumetric sorption heat, down to $0.4 \mathrm{GJ} / \mathrm{m}^{3}$. Considering that water based sensible heat storage, operating with a temperature gradient of $40 \mathrm{~K}$, can achieve about $0.17 \mathrm{GJ} / \mathrm{m}^{3}$, it is clear that these composites can help in achieving higher TES density. Furthermore, the absence of heat losses over long stand-by periods makes this approach even more profitable. Similarly, for DHW applications, silica gel-based composites achieve the highest volumetric sorption heat, about $0.4 \mathrm{GJ} / \mathrm{m}^{3}$, while the vermiculite-based one reaches up to $0.3 \mathrm{GJ} / \mathrm{m}^{3}$. Also, in this case, the advantage over sensible water storage is relevant, especially since, due to the higher delivering temperature, the temperature gradient under which the sensible storage can operate is lower than the one that exploitable for DHW applications, thus further limiting the overall volumetric storage density. 


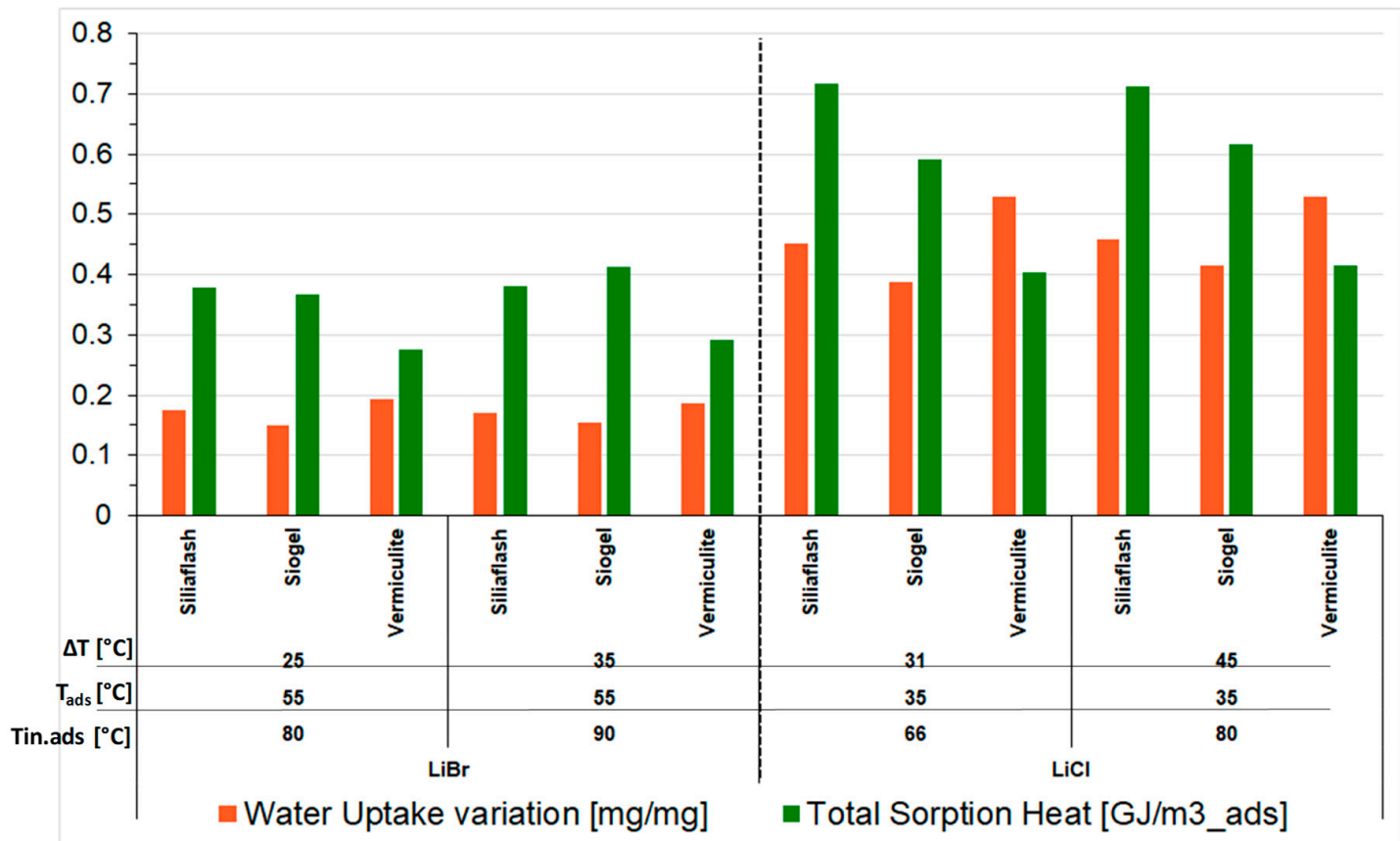

Figure 11. Water uptake variation and sorption heat measured for all the investigated sample in the TG/DSC apparatus, for the given temperature drop and keeping the water vapor pressure at $8.7 \mathrm{mbar}$, corresponding to $5{ }^{\circ} \mathrm{C}$ of evaporation temperature.

\section{Conclusions}

The reported paper presents the development and a comparative characterization of six composite sorbents suitable for thermal energy storage applications. Two different applications were considered, namely, low-temperature space heating $(\mathrm{SH})$ and domestic hot water (DHW). The synthetized composite sorbents consist of four silica gel (mesoporous Siogel and Siliaflash) based materials and two vermiculite-based sorbents, impregnated with $\mathrm{LiCl}$ or $\mathrm{LiBr}$, as hygroscopic salts. A deep experimental characterization was performed over the samples, whose main results are summarized below:

- $\quad$ The X-ray diffraction patterns of the composites confirmed the effective impregnation of the salt inside the matrixes. In particular, the samples kept at room temperature showed the presence of the crystalline hydrates of the salt, while the crystalline structure of the salt was perfectly recovered testing the samples at $90^{\circ} \mathrm{C}$.

- $\quad$ The $\mathrm{N}_{2}$ physisorption characterization performed before and after the impregnation of the mesoporous silica gels confirmed the effectiveness of the synthesis procedure. A slight deviation of the experimental pore volume of the composites from the theoretical one was highlighted, which can be due to partial deposition of the $\mathrm{LiCl}$ on the surface of the silica gel and partial blockage of the pores by LiBr. Nevertheless, a deviation lower than $10 \%$ from the theoretical values was identified. This indicates that the salts are mainly deposited inside pores.

- Water vapor adsorption isotherms at $35{ }^{\circ} \mathrm{C}$ were measured for each sample to comparatively evaluate achievable adsorption capacity and possible hysteresis effects between adsorption and desorption. The results showed that the vermiculite-based samples present an intermediate behavior between pure salt in bulk, where the hydration reaction is stepwise, and the silica gel-based samples, in which the salt confined in the mesopores shows more continuous increase in adsorption capacity at increasing relative pressure.

- Coupled TG/DSC analysis, mimicking the operating conditions of a STES, in which the adsorption is operated under pure water vapor atmosphere and applying a temperature drop over the sample, further highlighted the different behavior of the 
composites. Indeed, while the silica gel samples showed a narrow heat flux peak, the vermiculite-based ones were characterized by either a broad peak, in the case of $\mathrm{LiBr}$, or different consecutive peaks, in the case of $\mathrm{LiCl}$, demonstrating that the embedded salt causes a slowing down of the reaction.

- Finally, by integrating the obtained heat fluxes, the sorption heat was evaluated for all the samples. Despite the higher water vapor exchange capacity of the vermiculitebased samples, due to the higher salt content, the achievable volumetric sorption heat of the silica gel-based samples is always higher, due to the higher density of the samples. The most performing samples allowed to reach sorption heat of $0.7 \mathrm{GJ} / \mathrm{m}^{3}$ and $0.4 \mathrm{GJ} / \mathrm{m}^{3}$ for SH and DHW applications, respectively. These values are promising for the implementation of compact STES systems, to reduce the energy consumption due to the high heating demand of buildings.

Author Contributions: Conceptualization, V.B., L.G.G., and A.F.; Methodology, A.D.G., V.B., and L.G.G.; Validation, V.B. and A.C.; Formal analysis, V.B., L.G.G., and A.F.; Investigation, V.B., A.C., and A.F.; Resources, L.G.G. and A.F.; Data curation, V.B. and A.C.; Writing-original draft preparation, V.B. and A.F.; Writing-review and editing, L.G.G. and A.D.G.; Visualization, V.B. and A.C.; Supervision, L.G.G. and A.F.; Funding acquisition, A.F. All authors have read and agreed to the published version of the manuscript.

Funding: This project has received funding from the European Union's Horizon 2020 research and innovation program under grant agreement No. 764025 (SWS-HEATING). The Russian authors thank the Ministry of Science and Higher Education of the Russian Federation for partial financial support of this work within the governmental order for Boreskov Institute of Catalysis (project AAAA-A21-121011390006-0). The authors acknowledge the support of Dr. Elpida Piperopoulos (University of Messina) for the XRD analysis performed.

Data Availability Statement: The data presented in this study are available on request from the corresponding author.

Conflicts of Interest: The authors declare no conflict of interest.

\section{Nomenclature}

$\begin{array}{ll}\text { BET } & \text { Brunauer-Emmett-Teller theory } \\ \text { BJH } & \text { Barret-Joyner-Halenda theory } \\ \text { DHW } & \text { Domestic hot water } \\ \text { DSC } & \text { Differential scanning calorimetry } \\ \text { PCM } & \text { Phase change materials } \\ \text { SH } & \text { Space heating } \\ \text { STES } & \text { Sorption thermal energy storage } \\ \text { TES } & \text { Thermal energy storage } \\ \text { TGA } & \text { Thermogravimetric analysis } \\ \text { XRD } & \text { X-ray diffraction } \\ \Delta F & \text { Polaniy-Dubinin adsorption potential }\end{array}$

\section{References}

1. Giarola, S.; Molar-Cruz, A.; Vaillancourt, K.; Bahn, O.; Sarmiento, L.; Hawkes; A.; Brown, M. The role of energy storage in the uptake of renewable energy: A model comparison approach. Energy Policy 2021, 151, 112159. [CrossRef]

2. Behabtu, H.A.; Messagie, M.; Coosemans, T.; Berecibar, M.; Anlay Fante, K.; Kebede, A.A.; Mierlo, J.V. A Review of Energy Storage Technologies' Application Potentials in Renewable Energy Sources Grid Integration. Sustainability 2020, 12, 10511. [CrossRef]

3. Eurostat. Energy Consumption in Households-Statistics Explained. Available online: https://ec.europa.eu/eurostat/statisticsexplained /index.php?title=Energy_consumption_in_households\#Energy_consumption_in_households_by_type_of_end-use (accessed on 1 March 2021).

4. Pezzutto, S.; Croce, S.; Zambotti, S.; Kranzl, L.; Novelli, A.; Zambelli, P. Assessment of the Space Heating and Domestic Hot Water Market in Europe-Open Data and Results. Energies 2019, 12, 1760. [CrossRef]

5. Koçak, B.; Fernandez, A.I.; Paksoy, H. Review on sensible thermal energy storage for industrial solar applications and sustainability aspects. Sol. Energy 2020, 209, 135-169. [CrossRef] 
6. Gautam, A.; Saini, R.P. A review on sensible heat based packed bed solar thermal energy storage system for low temperature applications. Sol. Energy 2020, 207, 937-956. [CrossRef]

7. Jouhara, H.; Żabnieńska-Góra, A.; Khordehgah, N.; Ahmad, D.; Lipinski, T. Latent thermal energy storage technologies and applications: A review. Int. J. Thermofluids 2020, 5-6, 100039. [CrossRef]

8. Xiaofeng, X.; Xuelai, Z. Simulation and experimental investigation of a multi-temperature insulation box with phase change materials for cold storage. J. Food Eng. 2021, 292, 110286. [CrossRef]

9. Prieto, C.; Lopez-Roman, A.; Martínez, N.; Morera, J.M.; Cabeza, L.F. Improvement of Phase Change Materials (PCM) Used for Solar Process Heat Applications. Molecules 2021, 26, 1260. [CrossRef]

10. Korpyś, M.; Dzido, G.; Al-Rashed, M.H.; Wójcik, J. Experimental and numerical study on heat transfer intensification in turbulent flow of CuO-water nanofluids in horizontal coil. Chem. Eng. Process.-Process Intensif. 2020, 153, 107983. [CrossRef]

11. Desai, F.; Sunku Prasad, J.; Muthukumar, P.; Rahman, M.M. Thermochemical energy storage system for cooling and process heating applications: A review. Energy Convers. Manag. 2021, 229, 113617. [CrossRef]

12. Palomba, V.; Frazzica, A. Recent advancements in sorption technology for solar thermal energy storage applications. Sol. Energy 2018, 192, 69-105. [CrossRef]

13. Piperopoulos, E.; Fazio, M.; Mastronardo, E.; Lanza, M.; Milone, C. Tuning $\operatorname{Mg}(\mathrm{OH})_{2}$ Structural, Physical, and Morphological Characteristics for Its Optimal Behavior in a Thermochemical Heat-Storage Application. Materials 2021, 14, 1091. [CrossRef]

14. Gordeeva, L.G.G.; Aristov, Y.I. Composites "salt inside porous matrix" for adsorption heat transformation: A current state-of-theart and new trends. Int. J. Low-Carbon Technol. 2012, 7, 288-302. [CrossRef]

15. Frazzica, A.; Brancato, V.; Dawoud, B. Unified Methodology to Identify the Potential Application of Seasonal Sorption Storage Technology. Energies 2020, 13, 1037. [CrossRef]

16. Hauer, A. Sorption Theory for Thermal Energy Storage. In Thermal Energy Storage for Sustainable Energy Consumption; Paksoy, H.O., Ed.; Nato Science Series; Springer: Dordrecht, The Netherlands, 2007; Volume 234, pp. 393-408.

17. Hauer, A.; Fischer, F. Open Adsorption System for an Energy Efficient Dishwasher. Chem. Ing. Tech. 2011, 83, 61-66. [CrossRef]

18. Aydin, D.; Casey, S.P.; Chen, X.; Riffat, S. Novel “open-sorption pipe" reactor for solar thermal energy storage. Energy Convers. Manag. 2016, 121, 321-334. [CrossRef]

19. Sharma, R.; Anil Kumar, E. Study of ammoniated salts based thermochemical energy storage system with heat up-gradation: A thermodynamic approach. Energy 2017, 141, 1705-1716. [CrossRef]

20. Gordeeva, L.; Frazzica, A.; Sapienza, A.; Aristov, Y.; Freni, A. Adsorption cooling utilizing the "LiBr/silica—ethanol" working pair: Dynamic optimization of the adsorber/heat exchanger unit. Energy 2014, 75, 390-399. [CrossRef]

21. Grekova, A.; Gordeeva, L.; Aristov, Y. Composite sorbents "li/Ca halogenides inside Multi-wall Carbon Nano-tubes" for Thermal Energy Storage. Sol. Energy Mater. Sol. Cells 2016, 155, 176-183. [CrossRef]

22. Tatsidjodoung, P.; Le Pierrès, N.; Heintz, J.; Lagre, D.; Luo, L.; Durier, F. Experimental and numerical investigations of a zeolite 13X/water reactor for solar heat storage in buildings. Energy Convers. Manag. 2016, 108, 488-500. [CrossRef]

23. Jaehnig, D.; Hausner, R.; Wagner, W.; Isaksson, C. Thermo-chemical storage for solar space heating in a single-family house. In Proceedings of the EcoStock Conference, Richard Stockton College of New Jersey, Galloway, NJ, USA, 31 May-2 June 2006.

24. Brancato, V.; Frazzica, A. Characterisation and comparative analysis of zeotype water adsorbents for heat transformation applications. Sol. Energy Mater. Sol. Cells 2018, 180, 91-102. [CrossRef]

25. Elsayed, A.; Elsayed, E.; AL-Dadah, R.; Mahmoud, S.; Elshaer, A.; Kaialy, W. Thermal energy storage using metal-organic framework materials. Appl. Energy 2017, 186, 509-519. [CrossRef]

26. Zhang, X.; Li, M.; Shi, W.; Wang, B.; Li, X. Experimental investigation on charging and discharging performance of absorption thermal energy storage system. Energy Convers. Manag. 2014, 85, 425-434. [CrossRef]

27. Fumey, B.; Weber, R.; Baldini, L. Liquid sorption heat storage-A proof of concept based on lab measurements with a novel spiral fined heat and mass exchanger design. Appl. Energy 2017, 200, 215-225. [CrossRef]

28. Wu, W.; Bai, Y.; Huang, H.; Ding, Z.; Deng, L. Charging and discharging characteristics of absorption thermal energy storage using ionic-liquid-based working fluids. Energy 2019, 189, 116126. [CrossRef]

29. Frazzica, A.; Freni, A. Adsorbent working pairs for solar thermal energy storage in buildings. Renew. Energy 2017, 110, 87-94. [CrossRef]

30. Frazzica, A.; Brancato, V.; Caprì, A.; Cannilla, C.; Gordeeva, L.G.G.; Aristov, Y.I. Development of "salt in porous matrix" composites based on $\mathrm{LiCl}$ for sorption thermal energy storage. Energy 2020, 208, 118338. [CrossRef]

31. Brancato, V.; Gordeeva, L.G.G.; Grekova, A.D.; Sapienza, A.; Vasta, S.; Frazzica, A.; Aristov, Y.I. Water adsorption equilibrium and dynamics of LICL/MWCNT/PVA composite for adsorptive heat storage. Sol. Energy Mater. Sol. Cells 2019, 193, 133-140. [CrossRef]

32. Grekova, A.D.; Gordeeva, L.G.G.; Aristov, Y.I. Composite "LiCl/vermiculite" as advanced water sorbent for thermal energy storage. Appl. Therm. Eng. 2017, 124, 1401-1408. [CrossRef]

33. Gaeini, M.; van Alebeek, R.; Scapino, L.; Zondag, H.A.; Rindt, C.C.M. Hot tap water production by a 4 kW sorption segmented reactor in household scale for seasonal heat storage. J. Energy Storage 2018, 17, 118-128. [CrossRef]

34. van Alebeek, R.; Scapino, L.; Beving, M.A.J.M.; Gaeini, M.; Rindt, C.C.M.; Zondag, H.A. Investigation of a household-scale open sorption energy storage system based on the zeolite 13X/water reacting pair. Appl. Therm. Eng. 2018, 139, 325-333. [CrossRef] 
35. Li, W.; Klemeš, J.J.; Wang, Q.; Zeng, M. Energy Storage of Low Potential Heat using Lithium Hydroxide Based Sorbent for Domestic Heat Supply. J. Clean. Prod. 2021, 285, 124907. [CrossRef]

36. Aristov, Y.I. Challenging offers of material science for adsorption heat transformation: A review. Appl. Therm. Eng. 2013, 50, 1610-1618. [CrossRef]

37. Aristov, Y.I.; Tokarev, M.M.; Sharonov, V.E. Universal relation between the boundary temperatures of a basic cycle of sorption heat machines. Chem. Eng. Sci. 2008, 63, 2907-2912. [CrossRef]

38. Aristov, Y.I. New family of solid sorbents for adsorptive cooling: Material scientist approach. J. Eng. Thermophys. 2007, 16, 63-72. [CrossRef]

39. Gordeeva, L.; Aristov, Y. Novel sorbents of ethanol "salt confined to porous matrix" for adsorptive cooling. Energy 2010, 35, 2703-2708. [CrossRef]

40. Project TM. Materials Data on LiBr by Materials Project. 2020. Available online: https://materialsproject.org/materials/mp-2325 9/\#xrd-panel (accessed on 20 April 2021).

41. Project TM. Materials Data on LiCl by Materials Project. 2020. Available online: https://materialsproject.org/materials/mp-2290 5/\#xrd-panel (accessed on 20 April 2021).

42. Donohue, M.; Aranovich, G. Classification of Gibbs adsorption isotherms. Adv. Colloid Interface Sci. 1998, 76-77, 137-152. [CrossRef]

43. Brancato, V.; Gordeeva, L.G.G.; Sapienza, A.; Palomba, V.; Vasta, S.; Grekova, A.D.; Frazzica, A.; Aristov, Y.I. Experimental characterization of the $\mathrm{LiCl} /$ vermiculite composite for sorption heat storage applications. Int. J. Refrig. 2019, 105, 92-100. [CrossRef]

44. Gordeeva, L.G.G.; Aristov, Y.I. Composite sorbent of methanol "LiCl in mesoporous silica gel” for adsorption cooling: Dynamic optimization. Energy 2011, 36, 1273-1279. [CrossRef]

45. Frazzica, A.; Sapienza, A.; Freni, A. Novel experimental methodology for the characterization of thermodynamic performance of advanced working pairs for adsorptive heat transformers. Appl. Therm. Eng. 2014, 72, 229-236. [CrossRef]

46. Shkatulov, A.; Gordeeva, L.G.G.; Girnik, I.S.; Huinink, H.; Aristov, Y.I. Novel adsorption method for moisture and heat recuperation in ventilation: Composites "LiCl/matrix" tailored for cold climate. Energy 2020, 201, 117595. [CrossRef] 